\title{
FAKTOR RISIKO ANEMIA TERHADAP PLASENTA RINGAN PADA IBU BERSALIN Asrini $^{1}{ }^{1}$ Ratni ${ }^{1}$, A.Fahira Nur ${ }^{2}$ \\ ${ }^{1}$ Mahasiswa Kebidanan STIKES Widya Nusantara Palu ${ }^{2}$ Bagian Kebidanan STIKES Widya Nusantara Palu
}

\section{*E-mail : asriniriny@gmail.com}

Anemia dalam kehamilan dapat mengakibatkan dampak yang membahayakan ibu dan janin, bila terjadi sejak awal kehamilan dapat memicu terjadinya persalinan prematur, pertumbuhan janin terhambat yang dapat mengakibatkan penyakit kardiovaskular pada saat dewasa, dan dapat mempengaruhi vaskularisasi plasenta dengan mengganggu angiogenesis pada kehamilan muda. Anemia pada ibu hamil dapat dikaitkan dengan penurunan berat plasenta dan kelainan struktural dari plasenta, yang pada gilirannya mempengaruhi transportasi nutrisi dari ibu ke janin ${ }^{2,3}$. Kapasitas pertumbuhan berat janin dipengaruhi oleh pertumbuhan plasenta dan terdapat korelasi kuat antara berat plasenta dengan berat badan lahir $^{2}$. Berat plasenta mencerminkan fungsi dan perkembangan plasenta itu sendiri dan besar plasenta juga dapat memprediksi kemungkinan terjadinya hipertensi dikemudian hari. Sehingga anemia,salah satu yang menjadi penyebab berat plasenta ringan $^{7}$.

Berikut ini penulis akan membahas tentang risiko anemia pada ibu hamil terhadap berat plasenta ringan.

\section{Tinjauan Tentang Plasenta}

Plasenta adalah organ yang sangat penting untuk menjaga kelangsungan kehamilan karena plasenta berperan untuk pertukaran $\mathrm{O} 2$ dan transfer nutrisi dalam pertumbuhan janin. Plasenta normal berbentuk ceper dan bulat, diameter $15-20 \mathrm{~cm}$ dan tebal $11 / 2-3 \mathrm{~cm}$, pada kehamilan cukup bulan, berat plasenta normal $500-600$ gram $^{8}$. 

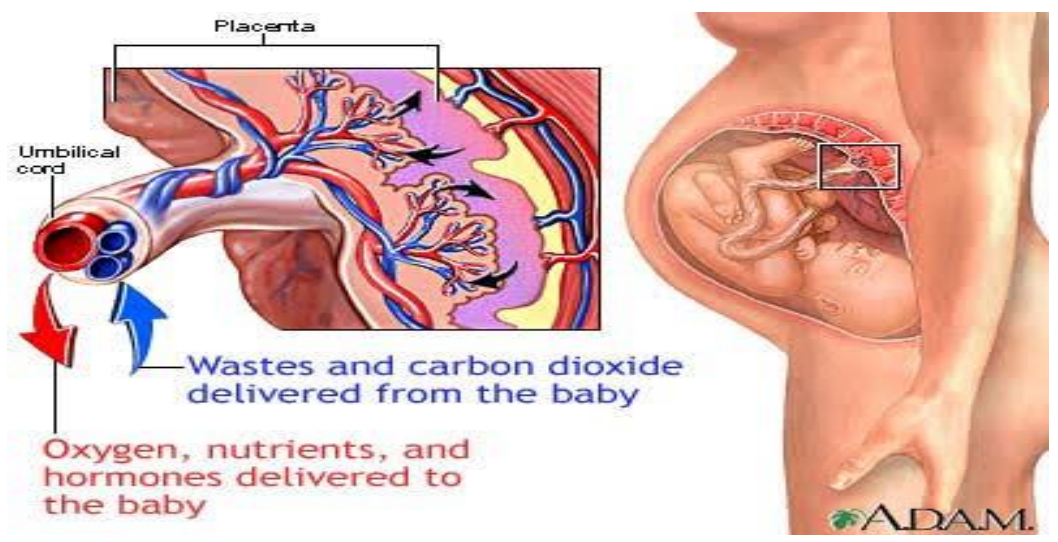

Plasenta berfungsi untuk nutritif, oksigenasi, ekskresi. dan penyaluran oksigen serta zat makanan dari ibu ke janin. Pertumbuhan plasenta dapat mempengaruhi kapasitas pertumbuhan berat janin karena terdapat korelasi kuat antara berat plasenta dengan berat badan lahir. Berat plasenta mencerminkan fungsi dan perkembangan plasenta itu sendiri dan berat plasenta juga dapat memprediksi kemungkinan terjadinya hipertensi dikemudian hari, sebaliknya plasenta ringan dapat mengindikasikan adanya kekurangan asupan nutrisi ke plasenta sehingga terjadi hipoksia plasenta yang pada akhirnya mengganggu fungsinya sehingga dapat berdampak pada bayi dengan Berat Badan Lahir Rendah (BBLR) ${ }^{6,7,8}$

\section{Tinjauan Tentang Faktor Risiko Berat Plasenta}

Berat plasenta berkaitan dengan beberapa faktor penting dan kelahiran neonatus. Berat plasenta merupakan suatu peringatan yang sangat terkait dengan pertumbuhan plasenta selama kehamilan. Faktor-faktor yang berhubungan dengan berat plasenta yaitu usia, paritas, Anemia, penyakit, pendapatan, status nutrisi, dan merokok ${ }^{4}$.

Anemia dapat membahayakan ibu dan janin, sehingga dapat memicu terjadinya persalinan prematur, pertumbuhan janin terhambat 
yang dapat mengakibatkan penyakit kardiovaskular pada saat dewasa, dan dapat mempengaruhi vaskularisasi plasenta ${ }^{1,5}$. Anemia sangat berkaitan dengan adanya penurunan berat plasenta dan kelainan struktural dari plasenta, yang pada gilirannya mempengaruhi transportasi nutrisi dari ibu ke janin. Anemia berdampak buruk pada peningkatan angka kematian ibu dan bayi ${ }^{7,4}$.

\section{Tinjauan Tentang Anemia Terhadap Plasenta Ringan}

Plasenta berfungsi untuk nutritif, oksigenasi, ekskresi, dan penyaluran oksigen serta zat makanan dari ibu ke janin. Ketika anemia terjadi pada ibu hamil dapat mengganggu penyaluran oksigen dan zat makanan dari ibu ke janin. Yang dapat mengakibatkan terjadinya gangguan plasenta seperti hipertropi plasenta dan villi yang mempengaruhi berat plasenta, klasifikasi, dan infrak, sehingga terjadi gangguan fungsinya. Hal ini dapat mengakibatkan gangguan pertumbuhan janin ${ }^{7,8}$.

Anemia sebagai salah satu faktor resiko terjadinya pertumbuhan plasenta yang tidak proporsional. berat plasenta sangat mencerminkan akan fungsi dan perkembangan plasenta itu sendiri dan besar plasenta juga memprediksi kemungkinan terjadinya hipertensi dikemudian hari Berat plasenta yang kecil dapat mengindikasikan adanya kekurangan asupan nutrisi ke plasenta sehingga terjadinya hipoksia plasenta yang pada akhirnya mengganggu fungsinya ${ }^{7}$.

Penelitian ini juga sejalan dengan pendapat yang mengatakan bahwa anemia dalam kehamilan dapat mengakibatkan adanya dampak yang membahayakan ibu dan janin, bila terjadi sejak awal kehamilan ini sangat memicu terjadinya persalinan prematur, pertumbuhan janin terhambat yang dapat mengakibatkan penyakit kardiovaskular pada saat dewasa, dan dapat mempengaruhi vaskularisasi plasenta dengan mengganggu angiogenesis pada kehamilan muda 1,5. Anemia berdampak buruk pada peningkatan angka kematian ibu dan bayi serta penurunan produktivitas kerja dan kemampuan belajar. Selain itu, anemia pada ibu hamil dapat menyebabkan pendarahan sebelum dan 
pada saat melahirkan, keguguran, kelahiran bayi prematur dan Berat Bayi Lahir Rendah ${ }^{2,3}$. 


\section{DAFTAR PUSTAKA}

1. A.Fahira Nur, Adhar Arifuddin, Hermiyanti (2018). Faktor Risiko Plasenta Ringan Pada Ibu Bersalin Di RSU Anutapura Palu. Jurnal Kesehatan Tadulako Vol. 4 No. 1, Januari 2018 : 1-56 http://jursnal.untad.ac.id/jurnal/index.php/HealthyTadulako/article/view/8 $\underline{750}$ diakses pada tanggal 28 September 2019. 